\title{
Pre-service EFL Teachers' Voices on Designing and Implementing Lesson Plan for Online Learning
}

\author{
Euis Rahmawati ${ }^{1}$, Hilmansyah Saefullah ${ }^{2}$, Sumarta ${ }^{3}$ \\ ${ }^{1}$ English Education Department, Singaperbangsa Karawang University, Indonesia \\ ${ }^{2}$ English Education Department, Singaperbangsa Karawang University, Indonesia \\ ${ }^{3}$ English Education Department, Singaperbangsa Karawang University, Indonesia
}

*Corresponding Author. E-mail: ${ }^{1}$ Rahmawatieuis989@gmail.com

Receive: 13/05/2021

Accepted: 23/08/2021

Published: 01/10/2021

\begin{abstract}
Designing and implementing a lesson plan is a complex process, so that according to several studies, the pre-service EFL teachers still had difficulties during designing and implementing a lesson plan. As novice designers, pre-service EFL teachers still lack of knowledge and expertise. Therefore, this study aims to find out the voices of the pre-service EFL teachers about their own experiences in designing and implementing their lesson plans. Five pre-service EFL teachers who had experienced to design and implement a lesson plan in the teaching practicum program during the Covid-19 pandemic outbreak at Senior High Schools in Karawang were recruited as the research participants. This study uses a qualitative approach and uses collective case studies research design. Online written interviews and virtual observation were conducted to collect data as information to answer the research question, and the interview data were then analyzed using thematic analysis. This research found out that designing and implementing lesson plans practiced by the pre-service EFL teachers during the teaching programs were perceived as decision-making process, non-negotiable process, and challenging process.
\end{abstract}

Keywords: Lesson plan design, lesson plan implementation, pre-service EFL teacher, online teaching practicum

\section{INTRODUCTION}

Designing a lesson plan in language teaching practice is an essential part of pedagogical procedures since it guides overall activities for the teacher in classroom activities. The successes of teachers in the classroom to gain the learning objectives mostly depend on the effective lesson plan and its implementation. This is because effective teaching deals with effective lesson planning (Johnson, 2000; Sahin-Taskin, 2017).
As lesson plan designers in the novice stage (Enow \& Goodwyn, 2018), pre-service EFL teachers may not have more experience, knowledge, expertise, fluency, and efficiency in the teaching field as what the experience English teachers have (Gün 2014; Kola, 2019; Li \& Weicheng, 2017). Tagle et al. (2020) reported in their study that to design lesson plans, pre-service EFL teachers should be equipped with several types of knowledge: pedagogical content knowledge, content knowledge, educational knowledge, curricular knowledge, general pedagogical knowledge, and knowledge of learners. Therefore, designing a lesson plan is known as not an 
easy process, but it is a complex and challenging process.

Although pre-service EFL teachers have been prepared in university preparation programs to create and plan particular learning instructions (Land \& Rubin 2018), most of them still not able to design an effective lesson plan. Pre-service EFL teachers are revealed they still find it challenging on how to design an appropriate assessment, and are dominant to use traditional teaching and learning approach, and lack of knowledge on how to evaluate the learning process and determine the students' achievement degree (Boikhutso, 2010; Cooper Hansen, 2006).

Furthermore, previous authors' works provide clear pieces of evidence of how complex and challenging pre-service EFL teachers try to design and implement their lesson plans into their classrooms. Sahin-Taskin (2017) reported that preservice EFL teachers cannot adapt the particular activities on the followed guide book, textbook, modules, or syllabus. Furthermore, they also have difficulty understanding their students' needs, levels, and characteristics because they do not have enough time to observe them. Thus, pre-service EFL teachers are also mostly faced difficulties in choosing and developing appropriate learning activities related to their students' interest, need and level.

Furthermore, Ansyari (2018) also reported that during the process of designing a lesson plan, most pre-service EFL teachers are still struggling on how to write good learning objectives, defining their role as teachers, determine the learning activities, and have difficulty in allocating much of the time pre-service EFL teachers needed for the learning activities.

Alanazi (2019) additionally reported that many pre-service EFL teachers still faced the problem of designing appropriate activities $d$ because they struggled to choose the final activities. They also have difficulty knowing how to apply the teaching method because pre-service EFL teachers are lack proficiency to determine the appropriate teaching method and technique.

Moreover, the 21st century and COVID-19 pandemic demand indirectly expect them to design and implement lesson plans that integrate technology in the teaching and learning process and do physical distancing. This kind of lesson plan is termed a technology-infused lesson plan due to lesson plan can facilitate teachers to integrate technology in the classroom (Janssen et al., 2019).
Consequently, pre-service English teachers must be competent to create learning activities and select appropriate technology in their classroom, to prevent losing their students' learning motivation and confidence toward the language learning purposes (Rahimi \& Pourshahbaz, 2019). However, according to a previous study conducted by Janssen et al. (2019), pre-service teachers only had adequate occasion to integrate technology with pedagogy and content.

Furthermore, from previous works that empirically show how complex and struggling designing lesson plan process is, these obstacles may affect pre-service EFL teachers' evaluation toward designing lesson plan process. This will further affect pre-service EFL teachers' ideas and original insight into their perceptions. In addition, being observed and evaluated by the university supervisor or mentor during processing teaching practicum is affecting pre-service EFL teachers' anxiety because they are afraid to make any mistake (Paker, 2011). Therefore, to fill this void, this research attempts to explore deeper pre-service EFL teachers' experiences toward the process in designing their lesson plan in a teaching practicum and explore their experiences in implementing their original lesson plan during the COVID-19 outbreak.

This study is aimed to know pre-service EFL teachers' responses toward experiencing to design and implement lesson plan for online language learning in teaching practicum at senior high schools. Therefore, this study explores the experience of designing and implementing lesson plan that practiced by pre-service EFL teachers. This is in line with the research formulation of the research problem follow:

1. How are pre-service EFL teachers' experiences in designing and implementing lesson plan in teaching practicum program during online learning?

In addition, taking into account the research's practical and theoretical significance, thus this research's findings may provide significant insights for pre-service EFL teachers concerning designing and implementing lesson plans and indirectly show obstacles that mostly they faced. Additionally, this study is also able to provide acknowledge about preservice EFL teachers' professional competence development and it could show the merits of designing lesson plans especially practiced by preservice EFL teachers. 


\section{Designing Lesson Plan for Online Learning}

The lesson planning cycle is principally divided into several parts: designing the plan, implementing the plan, and evaluating the plan (Farrell, 2002). As the initial step in the lesson planning cycle, designing a lesson plan is termed as teachers' daily decisionmaking process to effectively achieve learning outcomes, before, during, and after the lesson, since it is a beneficial process that easier for teachers to outline the materials, content, timing, sequencing, activities, and also to prevent the unpredictable movements in the classroom (Farrell, 2002). Therefore, designing a lesson plan needs a particular ability to combine particular components for the language teaching process to become coherent and help teachers planning the language classroom activities.

However, since there is no certain framework that should be followed by pre-service EFL teachers for designing a lesson plan, thus lesson plan components themselves can be constructed by learning objective, introduction, input, activity, and review (Johnson, 2000). Meanwhile, Ruys, Keer, \& Aelterman (2012) mentioned that a lesson plan could consist of learning objectives, materials, procedures, time, and evaluation.

However, in the Indonesian context, based on Indonesian Minister of National Education and Culture Regulation Number 14 the Year 2019, lesson plan components are divided into three main elements, they are (1) learning goal, (2) learning procedures, and (3) assessments. This lesson plan model is called 'a Single sheet lesson plan". It could help EFL teachers freely design, develop and use their lesson plan based on three main principles; effective, efficient, and centered on learners. Furthermore, this lesson plan framework is also appropriate for easier designing online learning during the COVID-19 outbreak.

Online learning can be defined as all types of learning via computers, such as E-learning, Webbased training, Computer-based training, or Technology-based instruction (Carliner, 2004). Therefore, designing online learning courses can be termed technology-infused lesson plans (Janssen, Knoef, \& Lazonder, 2019). A technology-infused lesson plan integrates technology into the pedagogical process and lesson plan preparation process (Janssen, Knoef, \& Lazonder, 2019). Thus, teachers can use technology in online learning for managing, developing, or delivering learning materials to attain future results (Carliner, 2004).

Janssen \& Lazonder (2016) reported that the quality of a lesson plan with technology integration support that pre-service teachers will design would be better than the lesson plan without technology support. Therefore, before planning a lesson, teachers must consider several main points, such as learning goals, technology that will be integrated, and project issues (Carliner, 2004). Then, as another beginning step, pre-service teachers who will design technology-infused lesson plans should be equipped with technology pedagogical and content information first, both in an integrated way or a separate way. Therefore, pre-service teachers can fully integrate technological, pedagogical, and content during designing lesson plans for online learning since they are already equipped with rich information backgrounds.

\section{Pre-service EFL Teachers: Novice Lesson Plan Designers}

Teachers who have experienced learning and teaching English lessons as a foreign language are termed pre-service EFL teachers (Hudson, Nguyen \& Hudson, 2008; Amalia \& Imperiani, 2013). This means pre-service EFL teachers are also those who have experienced writing lesson plans in teaching practicum. Enow \& Goodwyn (2018) revealed that pre-service EFL teachers are lesson plan designers in the novice stage. Thus, pre-service EFL teachers can learn to write a good lesson plan from more experienced teachers and see how they implement it into the class (Woodward 2001).

Previous works prove that most pre-service EFL teachers are still facing many difficulties and obstacles in designing a particular lesson plan. Boikhutso (2010) testified that pre-service EFL teachers still struggle to design meaningful instructional objectives, dominant in using traditional teaching and learning approaches, and lack knowledge on how to evaluate the learning process and determine the students' achievement degree. In addition, Sahin-Taskin, (2017) reported that pre-service EFL teachers are also lack of ability to adapt the particular learning activities and have difficulty understanding the students' needs, levels, and characteristics. In a study from Ansyari (2018), pre-service EFL teachers are also still struggling to write good learning objectives, define their role as teachers, and determine the learning activities. They have difficulty in allocating much of the time pre- 
service EFL teachers needed for the learning activities.

Therefore, to design better lesson plans, Farrell (2002) suggested several initial things that pre-service EFL teachers should follow. The first way is by writing clear, appropriate, and observable learning outcomes. Farrell (2002) argues that the well-written outcomes on learning objectives themselves will help teachers focus on what students have to learn and guide them to choose the appropriate directions and activities. The next way is determining the steps of activities to accomplish the outlined learning objectives. In addition, Shrum and Glisan (1994), cited in Farrell (2002), reported steps of learning procedures themselves can be started by reviewing the previous activities, performing stimulation, presenting the instruction, closing, and following new activities.

\section{Implementing the Plan}

However, the most important and difficult phase after preparing the lesson is implementing the lesson plan itself. Farrell (2002) suggested two crucial things that teachers should notice in implementing the lesson plan phase; lesson variety and lesson rapidity. Teachers can vary the lesson activity choices and delivery by changing the tempo or by varying the activities' difficultness level to avoid students' boredom. Lesson timing can be developed by setting a not too long or too short activity, running together with the chosen techniques for delivering the activities and make clear activities' transition (Brown (1994) cited in Farrell, 2002). In addition, Farrell (2002) argues teachers can also vary the lesson only by transform the class organization.

\section{METHODOLOGY}

This study aims to explore pre-service EFL teachers' experiences designing and implementing their lesson plans in teaching practicum program during the COVID-19 pandemic outbreak. This study uses a qualitative study and is designed to acquire particular information of the situation is examined as much as possible based on participants' perspectives (Creswell, 2014).

The qualitative approach was used in this study because the collected data were in sentences, phrases, clauses, and words and then classified into particular categories to get a conclusion (Creswell,
2014). Therefore, a research design used by the researcher was a case study since the phenomenon that the researcher had explored was related to professional practice, and a case study can be used to analyze a particular process (Baxter \& Jack, 2008). In addition, the kind of case study that the researcher had used was the collective case study. This means the experience of designing and implementing lesson plans can be explored using case study research design.

\section{Research Site and Participant}

The participants involved in this study were five pre-service EFL teachers studying in an Indonesian state University in Karawang and doing teaching practicum in some schools in Karawang. The participants were recruited based on their willingness to participate in this study by filling out a consent form. Next, the participants were selected by checking the specific qualification requirements, such as having some basic knowledge about lesson planning in their university. The selected participants also had experienced in designing lesson plans during the teaching practicum program in the COVID-19 pandemic outbreak. All of the participants' names in this study were in pseudonym.

\section{Data Collection Technique}

The data of this research were all phrases and clauses given by pre-service English teachers about their experience in designing and implementing lesson plans during their teaching practicum program. In this study, the researcher used online written open-ended interviews for collecting the data. The online written interview was divided into two sections and conducted via Google form and WhatsApp. In addition, the interview's technique procedures themselves were adopted from Heigham and Croker (2009) steps guidance:

1. Preparing an interview by outlining a list of questions.

2. Setting up the interview by determining when, where and how long the interview will be conducted.

3. Getting the interaction right by opening the interview, going into the topics, and moving from one topic to the other.

4. Transcribe the data of the interview.

Furthermore, other techniques like documentation also will be conducted by researchers as the additional research technique. 


\section{Instrumentation}

In determining the interview instruments, the researcher adopted Farrell's (2002) design and implementing lesson plan theory as the indicators. Next, the researcher developed the indicators to become a list of interview questions. First of all, the researchers translated the list of questions into the Indonesian language to easier for the participants to understand and answer the questions. The researcher changed the structure of words and sentences without changing the meaning of the questions.

\section{Data Analysis}

Furthermore, after conducting the transcribing process toward the participants' interview results, thus researcher used thematic analysis procedures by Braun \& Clarke' (2012) as the main methodology to analyze and interpret the data. Furthermore, the steps are; (1) Familiarization, (2) Coding, (3) Finding themes, (4) Reviewing themes, (5) Defining and naming themes, (6) producing the report.

\section{FINDINGS AND DISCUSSION}

\section{Results}

\section{Decision making process}

The finding shows that designing and implementing lesson plans is admitted as a decisionmaking process. The data illustrate that pre-service EFL teachers had experienced choosing, collecting, and organizing the appropriate and interesting learning material for their students during designing lesson plans in teaching practicum programs.

During the teaching practicum program, how the participants selected the relevant and appropriate learning material for their students is represented in the following online written interview's answers.

"I had chosen appropriate learning materials for my students by considering current learning situations and conditions. I will choose the material that is easy to learn and easy to understand. This material is usually in the form of text and expressions. The material of course, is also based on the sources of learning materials that students have, learning material delivered in easy-to-understand language and using media that accessible for students." (Vignette 1, Wati)

"Commonly, besides adjusting the curriculum, student needs, and the results of discussions with the mentor teacher, I will select learning materials considers to the materials related to students' daily activities. Students will find it easier to learn material related to daily life and also material about things that are being discussed a lot, for example, procedure text material, about how they apply health protocols in their daily life." (Vignette 2, Putri)

Based on the interview data in Vignette 1, Wati stated that she had experienced setting and selecting the learning material by considering the learning condition and easy and comprehensible learning materials. In addition, Wati also had experienced creating learning materials about the genre of text and expression related to students' real life by using accessible learning media. It is in line with the data revealed by Putri in vignette 2 that she had experienced selecting appropriate and interesting learning materials by organizing the learning activity related to students' daily activities, current issues, or phenomena.

Furthermore, considering how the participants choose the appropriate learning materials' sources, one of the pre-service EFL teachers creates the learning materials by mixing the materials from the internet and students' handbooks. This is implied from Noer in her interview session as follows.

"By picking of from for several references, such as from the internet and several student handbooks, then I will choose which one is more suitable to be selected and be taught to students or I would mix the material from these two references." (Vignette 3, Noer)

Based on the interview data in Vignette 3, Noer explains that she chooses to use the internet and the students' guidance book as her learning material sources. Thus, the data shows that preservice EFL teacher had experienced the decisionmaking process of the lesson plan design by deciding whether Noer will choose the most appropriate learning material from the internet or students' guidance book.

In addition, the pre-service EFL teachers also had practiced in decision-making process during designing lesson plan by trying to conceptualize and create learning contents inspired by others, such as their tutors and the tutors in the online videos.

"I create my learning content inspired by tutors and some youtube videos. Because it is virtual learning, I have to master several virtual tools, such as video editing. The content that I create aims to make students not bored with the material, so I will make video content of the material using PowerPoint 
which is then added with a recording of my explanation." (Vignette 4, Noer)

Based on the data of the interview in Vignette 4, the data expose that Noer had practiced creatively create her lesson content. Her decision to make learning contents was inspired by the videos of learning contents made by their mentor and from the YouTube website. For setting and presenting her learning content, she will make an interesting video by putting the collected learning materials into the attractive Microsoft PowerPoint template added with recording audio of explanation in it. This aimed to engage students learning motivation.

Moreover, the pre-service EFL teachers also admitted that they had faced the decision-making process in designing lesson plans by planning and setting the realistic lesson timing; formulating and sequencing a lesson; arranging the learning activities 'sequences and transitions; and organizing delivery of learning activities and learning speed variation while implementing the lesson.

"Because the allocation of learning time is $2 x$ 45 minutes, I usually will explain the material for 30 minutes, do reading, speaking, listening, or writing activities (chosen according to material needs) for 30 minutes, then in the last 30 minutes I will provide evaluation questions by asking again about the material that has been studied previously." (Vignette 5, Wati).

"By carrying out learning in from easy to difficult level, first of all at the beginning of learning, I will give a detailed explanation of the material, and then continued by doing exercises." (Vignette 6, Wati)

"Learning activities are adjusted based on the needs of the material being studied. For example, if the material is about a narrative text, then the activity I choose is writing with students, usually writing down their experiences and then reading and speaking by reading out the writing results. However, if the material is about expression, students are usually required to carry out conversations with their friends." (Vignette 7, Wati)

"I try to vary the learning activities delivery by choosing the appropriate language style and easy to understand." (Vignette 8 , Wati)

"In delivering the material, it is attempted to be delivered at a tempo that is not too slow and not too fast so that students can understand the material well." (Vignette 9, Noer)

The interview data from some participants show several additional decision-making processes practiced by pre-service EFL teachers in designing and implementing lesson plans. For example, in vignette 5, Wati explains that she had to set the lesson timing by dividing the 90 minutes of available learning time into explaining the materials and guiding several learning activities of four different skills (reading, speaking, listening, and writing), including assessment. Wati, in vignette 7 exposed that she had to arrange and select the appropriate learning activities based on what learning material that students have to learn. She chooses writing, reading, and speaking activity whenever the learning material is about text genre like narrative text. In contrast, she chooses pair conversation as the learning activity whenever the learning material is about daily expressions.

In vignette 8 , Wati also reported that she had to creatively determine how to vary the learning activities delivery. Wati tried to vary her learning activities delivery by using the attractive and easy-tounderstand expressions. Based on Vignette 6, the extra decision-making process that Wati had experienced was outlining her lesson sequence by organizing the learning activities from the easiest to the hardest, in which students were asked to analyze the text first, then they tried to create their own text. In addition, in vignette 9 , Noer had tried to set the tempo of the learning materials delivery in a moderate way.

\section{Non-negotiable process}

The findings expose that designing a lesson plan that pre-service EFL teachers had experienced is viewed as a non-negotiable process because it consists of a systematic-determined process in syllabus and curriculum. During the practice of designing a lesson plan, the pre-service EFL teachers cannot determine the duration and the amount of time needed in every week and meeting by themselves and this is a non-negotiable process. This is because learning time durations had been determined in the curriculum and syllabus.

"The length of learning timing in class is adjusted to the curriculum used and the rules of the school itself. Considering the current online learning, learning time in class is very limited, so students can receive learning materials well." (Vignette 10 , Putri)

"Total of lesson time duration is $45 \times 2$ minutes or about 90 minutes for each meeting a week." (Vignette 11, Eva)

Based on the data of the interview in Vignette 10, Putri explains that learning time duration has 
been determined by the curriculum and the school regulation itself. In addition, In addition, in vignette 10 , Putri also says that the school limits the learning time duration to maintain the students' focus on online learning. In vignette 11, Eva reported that there are only 90 minutes available learning time duration a week.

In addition, the further data indicates while planning the learning material, the theme or topic for each lesson had been determined and arranged in the curriculum and syllabus.

"The material I made was adjusted to the syllabus, and then by perforce, students would accept the material I gave. Students would love to learn to depend on the teacher's characteristic or teaching style itself. In the teaching practicum program, I tried to share stories about my experience as a transition in delivering the material. In less formal class situations, students will not feel awkward to ask questions and involve themselves to discuss the material." (Vignette 12, Eva)

Based on the data of the interview in Vignette 12, Eva admitted that the learning material designed by her was selected based on what has been provided and arranged in the syllabus. Furthermore, she argued that her teaching style would affect whether her students liked or disliked the learning materials. Thus, Eva tried to vary the learning materials delivery by adding several kinds of transitions.

\section{Challenging process}

The last finding of this research shows that designing and then implementing a lesson plan is quite complex and challenging. Based on the data about their experiences in designing and implementing lesson plan, the pre-service EFL teachers found difficult to find and arrange the learning material. In addition, another data exposes that pre-service EFL teachers are challenged by a lack of available learning sources references.

"I'm having difficulty with the learning source. I use sources from school, one book, and one textbook. But from both sources were limited, and the discussion was minimal, so I had to look for other sources, and it wasn't easy to find because it had to be real books that were used by teachers." (Vignette 13, Eva)

In the online written interview, Eva exposed that in the process of selecting and organizing learning material, she felt difficult to find the appropriate materials for the lesson since there are lacks of available learning material references.

In addition, Eva also admitted that she struggled how to find the appropriate way to deliver her lesson material.

"There are certain difficulties. But for me, it might be in the way the material is delivered, such as it is difficult to determine the method, especially for four meetings so that students do not feel bored." (Vignette 14, Eva)

In Vignette 14, Eva says that she found difficulty in determining the delivery of the learning material. This is because Eva had to avoid students' boredom by using different variations in the delivery of the learning activities.

Meanwhile, extra data reported the other obstacles faced by the pre-service teachers in designing lesson plans.

"Yes, it's hard. As I wrote earlier, that when compiling and selecting learning activities, we must adapt to the needs of the students themselves. In addition, the current conditions where the implementation of online learning is also a difficult reason to choose appropriate learning activities." (Vignette 15, Putri)

"As I told you before, the learning activities are quite difficult. This online learning makes the space for students and teachers become limited." (Vignette 16, Lia)

Based on the data of the interview in Vignette 15. Putri had difficulties on how to adjust the learning activities with the students' needs. Putri also explains that it is difficult to find the appropriate lesson activities for online learning. In line with the data of the interview in Vignette 16, Lia exposes that it is also difficult for her to conduct learning activities in online learning. As a beginner, Lia argued that it was not easy for her to design and adopt learning activities for online learning. According to her, online learning obstructs her movements to implement the planned learning activities.

Moreover, the participants show the additional challenges in implementing lesson plans for online learning, and some of the unexpected changes often occur on the following prepared lesson plan components.

"The lesson timing, it is because sometimes we can't implement the time we designed in the lesson plans when practicing the learning process." (Vignette 17, Putri)

"In the main activity, it is because sometimes in the middle of an explanation, students ask to 
explain material that they didn't know before. So as a teacher, I also have to be quick to answer and explain any unexpected questions from students." (Vignette 18, Lia)

Based on the data of the interview in vignette 17. Putri explains that lesson timing is the component of the lesson plan that often changes in the implementation process. Putri faced difficulty in implementing the designed lesson timing on her lesson plan into her language classes. Furthermore, in vignette 18 , Lia shows that lesson plan component that often changes in the implementation process that struggled by her is lesson main activity. Lia explains that during implementing the main lesson activities she often faced unpredicted movement during the teaching process, as she has to answers several random questions from her students about the previous learning materials.

\section{Discussion of the Findings}

Based on the research findings, it can be concluded that designing and implementing a lesson plan is perceived as a decision-making process for the pre-service EFL teachers. Therefore, it can be implied that pre-service EFL teachers serve as the decision-makers in the lesson plan design process. In designing and implementing lesson plans during the teaching program, pre-service teachers were required to effectively decide on how they will lead their language learning to achieve the learning objectives.

This is in line with Farrell (2002), who defined designing lesson plans as teachers' daily decisionmaking process to effectively achieve learning outcomes. Furthermore, the collected data on this research findings show that the pre-service EFL teachers are involved in decision-making activities while designing a lesson plan, and such activities are (1) determining and organizing the appropriate and interesting learning material for their students; (2) conceptualizing and creating learning content; (3) planning and setting the realistic lesson timing; (4) formulating lesson sequencing; (5) choosing and controlling the learning activity arrangement and transition; and (6) determining the speed of learning variation and varying the delivers learning activities while implementing the lesson.

Furthermore, the second finding of designing a lesson plan can be categorized as a non-negotiable process. According to the collected data, there are several things in designing and implementing lesson plans that had been systematically determined. It can be exposed to pre-service EFL teachers' experiences during the practice of designing lesson plans in terms of determining the theme or topic of their learning materials. Therefore, since the topics of the learning materials have been determined by the curriculum and syllabus, pre-service EFL teachers had only to develop the learning contents related to the provided topics by selecting the particular materials from books, YouTube, or another internet platform. However, they also had to arrange the learning material as creatively as possible.

In addition, the second thing that had been systematically determined by school is the amount of learning time duration. Learning time duration is arranged based on the applied curriculum and the school regulation itself. In online learning, the learning time duration is limited by the school to maintain students' focus. For the example, the data show the provided learning time duration on the curriculum and syllabus is 90 minutes for each meeting a week.

The third research finding is not something new that is commonly found out in the results of research related to this topic. The previous works examined by the researcher showed that most of the other research findings, which the data show that pre-service EFL teachers had challenged to adapt learning activities for online learning since their movement got limited. Pre-service EFL teachers also had difficulties finding the appropriate learning materials and learning activities. Moreover, preservice EFL teachers still faced difficulty in implementing the designed lesson timing on their lesson plan and often faced unpredicted movement during the teaching process, as they have to answers several random questions from their students about the previous learning materials. These findings confirm the previous studies that pre-service EFL teachers are still facing many difficulties and obstacles during designing lesson plans (Alanazi, 2019; Ansyari, 2018; Boikhutso, 2010; Sahin-Taskin, 2017).

\section{CONCLUSION}

The designing lesson plan is beneficial to outline and set particular lesson procedures, remind the considered steps of learning, remember learning objectives that students have to reach, and as a future reference to better improve the future lesson process. It is in line with a previous study by Capel et 
al. (2018) that designing a lesson plan is useful in delivering the lesson. In addition, by designing and implementing a lesson plan, pre-service teachers will become more confident because they already know exactly what they are going to do in class since the lesson plan is viewed as a map.

This study is aimed to know pre-service EFL teachers' responses toward experiencing to design and implement a lesson plan for online language learning in teaching practicum at senior high schools. Therefore, this study explores the experience of designing and implementing lesson plans that practiced by pre-service EFL teachers. In addition, considering the research's practical and theoretical significance, thus this research's findings may provide significant insights for pre-service EFL teachers concerning the process of designing and implementing a lesson plan and also indirectly show obstacles that mostly appear. Additionally, this study can also acknowledge the decision-making and development process in designing and implementing a lesson plans, especially practiced by pre-service EFL teachers.

This study uses a qualitative approach and uses collective case studies research design. Participants in this study involved five pre-service EFL teachers who had experienced designing lesson plans during the teaching practicum program in the COVID-19 Pandemic outbreak. Online written interviews and virtual documentation are conducted to obtain data information related to the research question, and the interview data were then analyzed using thematic analysis.

According to the research findings and discussion, designing and implementing a lesson plan during teaching practicum program at Senior High School in Karawang is viewed by pre-service EFL teachers as a decision-making process since preservice EFL teachers have to decide to set and arrange ideas to select and organize the appropriate and interesting learning material, learning content; lesson timing, lesson sequencing; learning activity delivery. Furthermore, as a non-negotiable process, designing and implementing a lesson plan consists of several points that pre-service EFL teachers cannot originally set and organize, such as lessons' topics and available lesson times for each day and week. Besides that, pre-service EFL teachers were distracted by several obstacles during designing and implementing their lesson plans that make this process so challenging.
The researcher totally realizes that this research is still far from being perfect. However, hopefully, this research can provide beneficial information for the future researcher about the language teaching professional development process, especially in designing and implementing lesson plan process practiced by pre-service EFL teachers. It is also hopeful that this research may have a beneficial contribution in lesson plan design by pre-service EFL teachers

\section{REFERENCES}

[1] Alanazi, M. H. (2019). A Study of the PreService Trainee Teachers Problems in Designing Lesson Plans. Arab World English Journal (AWEJ), Volume 10. Number 1. March 2019 Pp.166 - 182 DOI: https://dx.doi.org/10.24093/awej/vol10no1. 15

[2] Amalia, L. L., \& Imperiani, E. D. (2013). Mentor coaching to help pre-service teachers in designing an effective lesson plan. Indonesian Journal of Applied Linguistics, 2(2), 275-280.

[3] Ansyari, M, F. (2018). Developing a rubric for assessing pre-service English teachers struggles with instructional planning. Cogent Education, 5:1, 1507175. To link to this article:

https://doi.org/10.1080/2331186X.2018.150 $\underline{7175}$

[4] Atai, M, R., \& Mazlum, F. (2013). English language teaching curriculum in Iran: planning and practice. Curriculum Journal, 24:3, 389-411, DOI: http://10.1080/09585176.2012.744327

[5] Baecher, L., Farnsworth, T., \& Ediger, A. (2013). The challenges of planning language objectives in content-based ESL instruction. Language Teaching Research, 2014, Vol 18(1) 118-136. DOI: http://10.1177/1362168813505381

[6] Baxter, P., \& Jack, S. (2008). Qualitative case study methodology: Study design and implementation for novice researchers. The qualitative report, 13(4), 544-559. 
[7] Bocala, C. (2015). From Experience to Expertise: The Development of Teachers' Learning in Lesson Study. Journal of Teacher Education. 2015, Vol. 66(4) 349-362

[8] Boikhutso, K. (2010). The theory into practice dilemma: Lesson planning challenges facing Botswana student-teachers. Improving School. Volume 9 Number 3 March 2006 0000, DOI: http://10.1177/1365480206061994

[9] Brown, H. D. (1994). Teaching by Principles An Interactive Approach to Language Pedagogy. Englewood Cliffs, NJ: Prentice Hall Refents

[10] Capel, S., Bassett, S., Lawrence, J., Newton, A., \& Zwozdiak-Myers, p. (2018). How trainee physical education teachers in England write, use and evaluate lesson plans. European Physical Education Review 25(4), 964-982.

DOI: http://10.1177/1356336X18785053

[11] Carliner, S (2004). An overview of online learning. (2nd ed.). Armherst, MA: Human Resource Development Press

[12] Cicek, V. (2013). Effective use of lesson plans to enhance education. International Journal of Economy, Management and Social Sciences, 2(6), 334-341.

[13] Clarke, V., Braun, V., \& Hayfield, N. (2015). Thematic analysis. Qualitative psychology: A practical guide to research methods, 222248.

[14] Creswell, J. W. (2014). A concise introduction to mixed methods research. SAGE publications.

[15] Cooper Hansen, C. (2006). Technology as an electronic mentor: Scaffolding preservice teachers in writing effective literacy lesson plans. Journal of Early Childhood Teacher Education, 27(2), 129-148.

[16] Ekanayake, T. M. S. S. K. Y., \& Wishart, J. M. (2014). Developing teachers' pedagogical practice in teaching science lessons with mobile phones. Technology, Pedagogy and Education, 23(2), 131-150., DOI: 10.1080/1475939X.2013.810366. To link to this article: http://dx.doi.org/10.1080/1475939X.2013.8 $\underline{10366}$
[17] Enow, L., \& Goodwyn, A. (2018). The invisible plan: how English teachers develop their expertise and the special place of adapting the skills of lesson planning. English in Education, DOI: http://10.1080/04250494.2018.1438119

[18] Farrell, T. S. (2002). Lesson planning. In Richards, J. C., Richards, J. C., \& Renandya, W. A. (Eds.). (2002). Methodology in language teaching: An anthology of current practice. Cambridge university press, 30-39.

[19] Gün, B. (2014). Making Sense of Experienced Teachers' Interactive Decisions: Implications for Expertise in Teaching. International Journal of Instruction 7 (1): 75-90.

[20] Heigham, J., \& Croker, R. (Eds.). (2009). Qualitative research in applied linguistics: A practical introduction. Springer.

[21] Hsu, L. (2016). Examining EFL teachers' technological pedagogical content knowledge and the adoption of mobileassisted language learning: A partial least square approach. Computer Assisted Language Learning, 29(8), 1287-1297, DOI: http://10.1080/09588221.2016.1278024

[22] Hudson, P. B., Nguyen, T. M. H., \& Hudson, S. (2008). Challenges for preservice EFL teachers entering practicum. In 2008 Asia TEFL International Conference: Globalizing Asia: The Role of ELT.

[23] Janssen, N., Knoef, M., \& Lazonder, A. W. (2019). Technological and pedagogical support for pre-service teachers' lesson planning. Technology, Pedagogy and Education, 28(1), 115-128.

[24] Janssen, N., \& Lazonder, A. W. (2015). Implementing innovative technologies through lesson plans: what kind of support do teachers prefer?. Journal of science education and technology, 24(6), 910-920.

[25] Janssen, N., \& Lazonder, A. W. (2016). Supporting pre-service teachers in designing technology-infused lesson plans. Journal of computer assisted learning, 32(5), 456-467.

[26] Johnson, A. P. (2000). It's time for Madeline Hunter to go: A new look at lesson plan design. Action in teacher education, 22(1), 72-78. 
[27] Kola, M. (2019). Pre-service teachers' action research: technology education lesson planning in a South African University. Educational Action Research, 1-19. doi:10.1080/09650792.2019.1686043, http://10.1080/09650792.2019.1686043

[28] Li, W., \& Weicheng, Z. (2017). A study of EFL teacher expertise in lesson planning. Teaching and Teacher Education 66 (2017) 231-241.

DOI: http://dx.doi.org/10.1016/j.tate.2017.04.009

[29] Land, C, L., \& Rubin, J, C. (2018). Part of the assignment: student-teachers' planning instruction within/across activity systems. Teaching Education, DOI: http://10.1080/10476210.2018.1546689

[30] Mutton, T., Hagger, H., \& Burn, K. (2011). Learning to plan, planning to learn: the developing expertise of beginning teachers. Teachers and Teaching: Theory and Practice 17 (4): 399-416. DOI: http://10.1080/13540602.2011.580516

[31] Paker, T. (2011). Student teachers' anxiety related to the teaching practicum. Egitim Arastirmalari-Eurasian Journal of Education Research, 42, 207-224

[32] Rahimi, M., \& Pourshahbaz, S. (Eds.). (2018). English as a Foreign Language Teachers' TPACK: Emerging Research and Opportunities: Emerging Research and Opportunities. IGI Global.

[33] Ruys, I., Keer, H. V., \& Aelterman, A. (2012). Examining pre-service teacher competence in lesson planning pertaining to collaborative learning. Journal of Curriculum Studies, 44(3), 349-379.

[34] Sahin-Taskin, C. (2017). Exploring Pre-Service Teachers' Perceptions of Lesson Planning in Primary Education. Journal of education and practice, 8(12), 57-63.

[35] Savin-Baden, M., \& Niekerk, L. V. (2007). Narrative Inquiry: Theory and Practice. Journal of Geography in Higher Education, 31(3), 459-472. doi:10.1080/03098260601071324

[36] Tagle, T., Díaz, C., Etchegaray, P., Alarcón, P., Quintana, M., \& Ramos, L. (2020). Lesson planning: What types of professional knowledge are activated by chilean preservice efl teachers?. Electronic Journal of Foreign Language Teaching, 17(1), 258-271.

[37] Walker, A., Recker, M., Ye, L., Robertshaw, M. B., Sellers, L., \& Leary, H. (2012). Comparing technology-related teacher professional development designs: A multilevel study of teacher and student impacts. Educational technology research and development, 60(3), 421-444.

[38] Windschitl, M., Lohwasser, K.,\& Tasker, T. (2020). Learning to Plan During the Clinical Experience: How Visions of Teaching Influence Novices' Opportunities to Practice. Journal of Teacher Education 1-14.

[39] Woodward, T (2001). Planning lessons and courses: Designing sequences of work for the language classroom. Cambridge: Cambridge University Press. 